\title{
Effect of advancing paternal age on semen parameters and seminal oxidative stress markers in infertile men
}

\author{
Saad Alshahrani ${ }^{1,2}$, Ashok Agarwal 1,3*, Mourad Assidi ${ }^{3,4}$, Adel M. Abuzenadah ${ }^{3,4}$, Damayanthi Durairajanayagam ${ }^{1,5}$, \\ Ahmet Ayaz ${ }^{1}$, Rakesh Sharma ${ }^{1}$, Edmund Sabanegh ${ }^{1}$
}

From 2nd International Genomic Medical Conference (IGMC 2013)

Jeddah, Kingdom of Saudi Arabia. 24-27 November 2013

\section{Background}

High rate of subfertility and adverse pregnancy related outcomes associated with childbearing are seen after age 40 . In contrast to oogenesis, spermatogenesis continues in elderly men. Adult male germ cells pass through significantly more mitotic replications than the germ cells in adult female. In men, there is an age associated increase in the incidence of breaks in sperm DNA, decrease in apoptosis, and a higher frequency of point mutations. Advanced paternal age is associated with an increased time to pregnancy and decreased pregnancy rates. After adjusting for female age, conception during a 12-month period was $>30$ percent less likely for men over 40 years of age as compared to men $<30$ years of age [1]. Similarly, a five-fold increase in time to pregnancy was reported in men $>45$ years compared to men $<25$ years of age [2]. Age of the husband was the most significant factor contributing to a decreased probability of a pregnancy [3]. Advanced paternal age may result in congenital anomalies in progeny due to an increase in new autosomal dominant mutations such as achondroplasia; Apert, Waardenburg, Crouzon, Pfeiffer, and Marfan syndromes [4]. The goal of our study was to investigate the impact of male ageing on semen quality and seminal oxidative stress $(\mathrm{OS})$ markers.

\section{Materials and methods}

In this study, we examined the medical records of 472 infertile men referred to our laboratory between 2008 and 2012. Based on their age, patients were divided into group $1: \leq 30$ years $(\mathrm{n}=69)$; group $2: 31-40$ years $(\mathrm{n}=298)$; and

\footnotetext{
* Correspondence: agarwaa@ccf.org

${ }^{1}$ Center for Reproductive Medicine, Cleveland Clinic, Cleveland, Ohio 44195, USA

Full list of author information is available at the end of the article
}

group 3:> 40 years $(n=105)$. We evaluated the conventional semen parameters (WHO, 2010) [5] and OS markers: seminal ROS (chemiluminescence assay), total antioxidant capacity (TAC) and sperm DNA damage (TUNEL assay) in all patients.

\section{Results}

The mean age of the study subjects was $36.8 \pm 6.7$ years. No age-related differences were seen in conventional semen parameters (volume, concentration, motility, and morphology) (Table 1). ROS and antioxidant levels were comparable in the 3 groups. Significantly higher levels of sperm DNA damage $(19.94 \pm 15.30 \%)$ was seen in infertile men $>40$ years compared to men in younger age groups $(\mathrm{P}=0.028$ and $\mathrm{P}=0.027$, respectively).

\section{Conclusions}

Sperm DNA damage increases with advancing paternal age. Evaluation of sperm DNA damage will help diagnose the underlying cause of poor fertility in some men and assist the clinician in offering correct treatment modality.

\section{Authors' details \\ ${ }^{1}$ Center for Reproductive Medicine, Cleveland Clinic, Cleveland, Ohio 44195 USA. ${ }^{2}$ Salman Bin Abdulaziz University, College of Medicine, Saudi Arabia. \\ ${ }^{3}$ Center of Excellence in Genomic Medicine Research, King Abdulaziz University, Jeddah, Saudi Arabia. ${ }^{4}$ KACST Technology Innovation Center for Personalized Medicine at King Abdulaziz University, Jeddah, Saudi Arabia. ${ }^{5}$ MARA University of Technology, Sungai, Selangor Darul Ehsan, Malaysia.}

Published: 2 April 2014

\section{References}

1. Ford WC, North K, Taylor H, Farrow A, Hull MG, Golding J: Increasing paternal age is associated with delayed conception in a large population of fertile couples: evidence for declining fecundity in older 
men. The ALSPAC Study Team (Avon Longitudinal Study of Pregnancy and Childhood). Hum Reprod 2000, 15:1703.

2. Hassan MA, Killick SR: Effect of male age on fertility: evidence for the decline in male fertility with increasing age. Fertil Steril 2003, 79:1520.

3. Mathieu C, Ecochard R, Bied V, Lornage J, Czyba JC: Cumulative conception rate following intrauterine artificial insemination with husband's spermatozoa: influence of husband's age. Hum Reprod 1995, 10:1090

4. Auroux M: Age of the father and development. Contracept Fertil Sex 1993, 21:382.

5. World Health Organization: WHO laboratory manual for the examination and processing of human semen. Geneva, Switzerland; Fifth 2010.

doi:10.1186/1471-2164-15-S2-P42

Cite this article as: Alshahrani et al:: Effect of advancing paternal age on semen parameters and seminal oxidative stress markers in infertile men. BMC Genomics 2014 15(Suppl 2):P42

Submit your next manuscript to BioMed Central and take full advantage of:

- Convenient online submission

- Thorough peer review

- No space constraints or color figure charges

- Immediate publication on acceptance

- Inclusion in PubMed, CAS, Scopus and Google Scholar

- Research which is freely available for redistribution

Submit your manuscript at www.biomedcentral.com/submit 